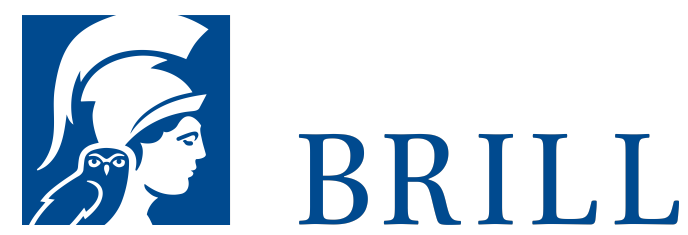

\title{
Griechische Geschichte
}

Von den Anfängen bis zum Beginn des Hellenismus

Author: Karl-Wilhelm Welwei

Karl-Wilhelm Welwei lässt auf Basis neuester archäologischer Funde die gesamte Geschichte des antiken Griechenlands Revue passieren - von den Anfängen bis zum Ende der Unabhängigkeit der Stadtstaaten durch Alexander den Großen. Er zeigt, wie sich in der Kleinräumigkeit der Lebenswelt nach dem Zusammenbruch der mykenischen Paläste Identitäten ausbildeten.

Erstmals stehen nicht nur die außenpolitischen Krisen wie die Perserkriege und der Konflikt zwischen Athen und Sparta im Zentrum der Betrachtung, auch die Randgebiete der griechischen Kultur werden berücksichtigt.

Neben der Ereignisgeschichte und den wirtschaftlichsozialen Strukturen erörtert der Autor wichtige Aspekte der hellenischen Kultur (v.a. das politische Denken). Seit langem die erste umfassende Darstellung einer faszinierenden weltgeschichtlichen Epoche - ein Standardwerk für alle, die sich das gewandelte Bild des antiken Griechentums erschließen wollen.

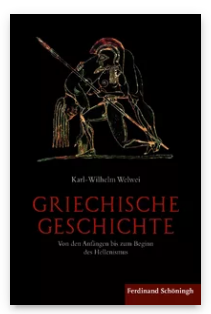

Pages: 587 Seiten, $34 \mathrm{~s} / \mathrm{w}$ Abb.

Language:

German

Subjects: Ancient History, Classical Studies Publisher: Brill | Schöningh

E-Book (PDF) Released online: O2 Jan 2012 ISBN: 978-3657-77306-o List price

\section{Hardback}

Publication date: o5 Oct 2011 ISBN: $978-3^{-}$ 506-77306-7 List price USD $\$ 75.00$ 
Karl-Wilhelm Welwei, Dr. phil. habil., geb. 1930, Studium der Geschichte und Klassischen Philologie in Köln; 19571965 im Schuldienst; seit 1966 Mitarbeiter am Projekt »Forschungen zur antiken Sklaverei« der Akademie der Wissenschaften und der Literatur Mainz; von 19721996 Professor für Alte Geschichte an der RuhrUniversität Bochum; seit 1993 Ordentliches Mitglied des Deutschen Archäologischen Instituts.

For more information see brill.com

$$
\begin{aligned}
& \text { Order information: Order online at brill.com } \\
& \text { +44 } 33 \circ 333 \text { o049 | customerservices@brill.com } \\
& \text { Submission information: brill.com/authors }
\end{aligned}
$$

Titles published by Brill | Fink, Brill | mentis or Brill | Schöningh: +49(o)71 5413279216 | brill@brocom.de 